\title{
DEVELOPMENT OF THE METHODOLOGY FOR THE ESTIMATION OF ENALAPRIL MALEATE IN MEDICINES
}

Introduction. Thin layer chromatography, or TLC, is a method for analyzing mixtures by separating the compounds in the mixture. TLC can be used to help determine the number of components in a mixture, the identity of compounds, and the purity of a compound.

The aim of the study - to develop a thin layer chromatography method for the estimation enalapril in medicines.

Research Methods. Analysis of enalapril maleate is described in State Pharmacopeia of Ukraine 2.2 but the aim of our study consisted in the development of rapid, simple, selective, more accurate, less expensive methods for analysis of enalapril maleate and their use for development of bioanalytical methods.

Results and Discussion. Method of identification of enalapril maleate in medicines by TLC was developed. We established that the most optimal Rf observed using mobile phase: ammonia (25\%) - propanol (30:70). The detection limits of enalapril maleate in this system are $0.2 \mathrm{mcg}$. However, those mobile phase is the most express. We explored the validation characteristics - specificity and suitability of the chromatographic system that met, the eligibility criteria established by the SPU.

Conclusions. We developed chromatographic methods of identification of enalapril maleate in medicines. The proposed method is rapid, economical and simple.

KEY WORDS: enalapril maleate; identification; thin layer chromatography; validation.

INTRODUCTION. Enalapril is medicines that belongs to the angiotensin-converting enzyme (ACE) inhibitor class of medications. It is rapidly metabolized in the liver to enalaprilat following oral administration. Enalaprilat is a potent, competitive inhibitor of $A C E$, the enzyme responsible for the conversion of angiotensin I (ATI) to angiotensin II (ATII). ATII regulates blood pressure and is a key component of the renin-angiotensin-aldosterone system (RAAS). Enalapril may be used to treat essential or renovascular hypertension and symptomatic congestive heart failure.

Analysis of enalapril maleate is described in State Pharmacopeia of Ukraine 2.2 but for identification there is IR-spectroscopy which almost need expensive equipment. So development of new, rapid, simple, selective, more accurate, less expensive method for analysis of enalapril is important task of pharmaceutical analysis.

Thin layer chromatography (TLC) is a popular technique for the analysis of a wide variety of organic and inorganic substances, because of its distinct advantages such as minimal sample cleanup, wide choice of mobile phases, flexibility in sample distinction, high sample loading capacity (c) L. S. Logoyda, D. B. Korobko, 2017. and low cost. The use of chromatographic techniques for monitoring the starting materials, intermediates and the process reactions is an excellent means for controlling the purity of the final drug and thereby protecting the patient who ultimately receives it. TLC is a powerful tool for screening unknown materials in bulk drugs. It provides a relatively high degree of assurance that all possible components of the drug are separated. The high specificity of TLC was exploited to quantitative analytical purpose using spot elution followed by spectrophotometric measurement. TLC plays a crucial role in the early stage of drug development when information about the impurities and degradation products in drug substance and drug product is inadequate. Various impurities of pharmaceuticals have been identified and determined using TLC $[1,2]$.

The aim of the study - to improve more rapid, simple, selective, more accurate, less expensive methods TLC analysis of enalapril maleate in medicines and for using this method of analysis for development of bioanalytical methods.

RESEARCH METHODS. Enalapril maleate was obtained as a gift from Farmak pharmaceuticals 
(Kyiv, Ukraine). All solvents were obtained from Merck pharamaceticals.

Analytical equipment

Scales AVT-120-5D, measuring vessel glass and reagents that meet the SPU requirements. TLC test was carried out using Silica gel, chromatographic plates 60 F254 "Merck" (Germany) and "Sorbfil" (Russia).

Sample preparation

Investigation solutions from tablets "Enalozid mono". To sample powder tablets or powder, equivalent to $10.0 \mathrm{mg}$ enalapril maleate, add $5.0 \mathrm{ml}$ of methanol $R$ and dilute with methanol $R$ to $10.0 \mathrm{ml}$, mix and filter.

Reference solution. $10.0 \mathrm{mg}$ Pharmacopoeial standard sample SPU of enalapril maleate dissolved in methanol $R$ and dilute with the same solvent to $10.0 \mathrm{ml}$.

Mobile phase: ammonia (25\%) - propanol (30:70).

Samples that are applied: $5 \mu \mathrm{l}$, applied the test solution and investigation solutions.

Over a path of $10 \mathrm{~cm}$ from the starting line.

Detection: a) examination in ultraviolet light at $254 \mathrm{~nm}$

b) spray with ninhydrin solution $R$ and dry at $100{ }^{\circ} \mathrm{C}$ for $15 \mathrm{~min}$.

RESULTS AND DISCUSSION. The present study assessed the different solvent extracts of enalapril maleate in medicines for TLC. For detection we used examination in ultraviolet light at $254 \mathrm{~nm}$ and spray with ninhydrin solution $\mathrm{R}$ and dry at $100^{\circ} \mathrm{C}$ for $15 \mathrm{~min}$ because in structure of enalapril there is a fragment similar to aminoacids. The chromatogram obtained with the test solution is detected at the main spot basic substance in the chromatogram obtained with reference solutions, corresponding in size and color. We had investigated various mobile phases (solvent system) in order to identify the optimal choice of enalapril maleate in medicines investigation by TLC. The factors of mobility in the studied of enalapril maleate in mobile phases, are listed in Table.

We found that for identification by TLC it should be used a sensitive of all investigated solvents. We established that the most optimal Rf was observed using mobile phases for enalapril maleate: ammonia (25\%) - propanol (30:70). The detection limit is $0.2 \mathrm{mcg}$. However, the most express mobile phase is ammonia (25\%) - propanol (30: 70$)$. The analysis considered probable, though the test requirements "Check suitability chromatographic system". Chromatographic system is considered appropriate when:

The chromatogram obtained with reference solution is a clearly visible spot;

Rf principle spot in the chromatogram obtained with reference solution to be about 0.6.

We previously studied the behavior of placebo tablets in terms of methods of identification of enalapril maleate. It was established that the excipients are part of tablets and do not affect the sensitivity and specificity of enalapril detection.

Validated analytical methods play an important role in achieving this goal. According to the SPU and Note for guidance on validation of analytical procedures: text and methodology (CPMP/ $\mathrm{ICH} / 381 / 95)$ to test the Identification must be validated, to determine such characteristics as specificity and suitability of the chromatographic system [3-6]. The maximum difference of $R f$ values in the same plate (for two series of plates) must not exceed the value of 0.02 . Originally, plates were tested according to the requirements of SPU on chromatographic resolution. When checking for the stability of the solution at the time we started chromatography of enalapril freshly prepared test solution sustained, over time for $30 \mathrm{~min}$. Visual

Table - Chromatographic characteristics of enalapril maleate

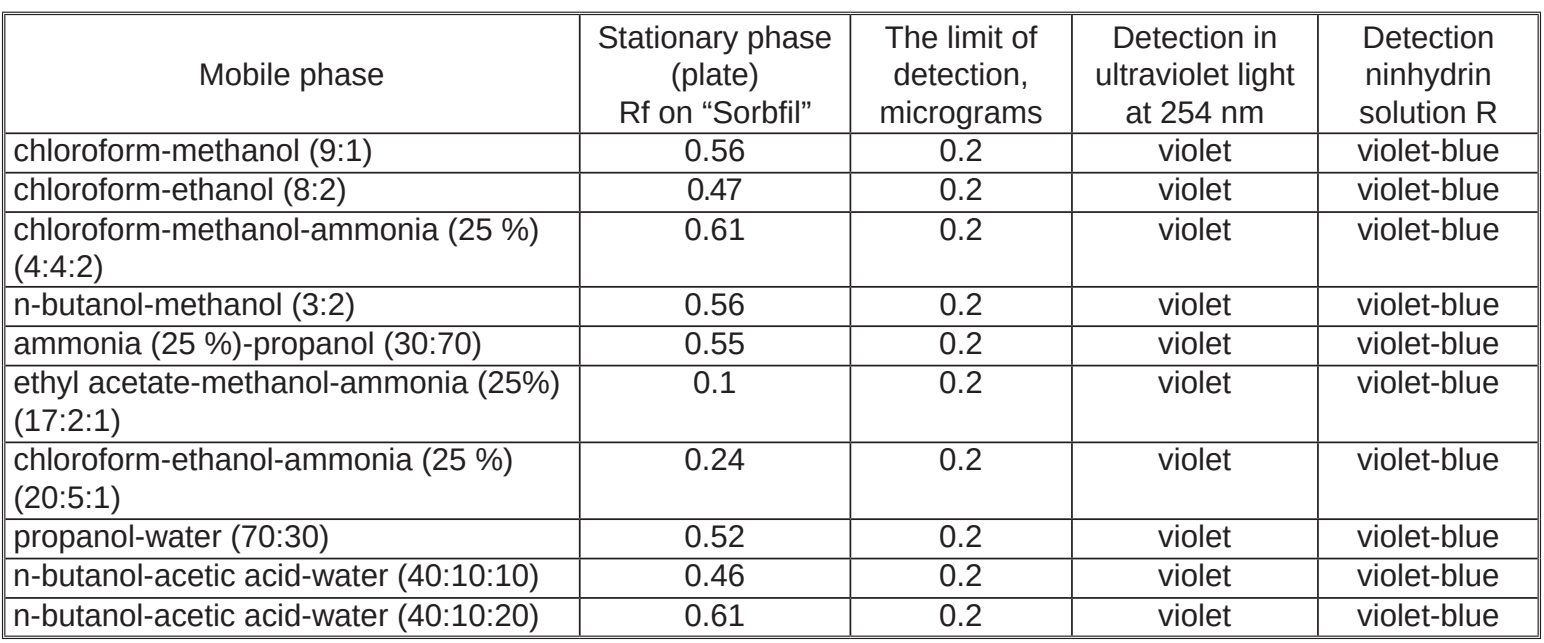


assessment of spots on the size and intensity of staining confirms that they clearly appear as freshly cooked and seasoned in time solutions (for plates of different series). The solutions were stable over time and new areas, had been identified. Thus, we explored the validation characteristics - specificity and suitability of the chromatographic system that met, the eligibility criteria established by the SPU.

CONCLUSIONS. In conclusion, we developed TLC methods of identification of enalapril maleate in medicines. We found that enalapril identification by TLC using a sensitive of all investigated solvents. We established that the most optimal Rf observed using mobile phases for enalapril maleate: ammonia (25\%) - propanol (30:70). The detection limit is 0.2 mcg. The validation study of the characteristics of both specificity and suitability of the chromatographic system, confirmed that they meet the eligibility requirements under the SPU.

\section{LIST OF LITERATURE}

1. www.medicines.org.uk

2. Review on analytical method development and validation. Research and reviews / R. Patil, T. Deshmukh, V. Patil, K. Khandelwal // Journal of Pharmaceutical Analysis. - 2014. - № 3 (3). P. 1-10.

3. ICH Topic Q2 (R1) Validation of analytical procedures: text and methodology.

4. Liliya L. Development of methods for identification of calcium channel blockers in medicines / L. Liliya, K. Dmutro, S. Stanislav // International Journal of Research Ayurveda Pharmaceutical. 2016. - № 7 (2). - P. 88-91.

\section{REFERENCES}

1. www.medicines.org.uk

2. Patil, R., Deshmukh, T., Patil, V., \& Khandelwal, K. (2014). Review on analytical method development and validation. Research and reviews. Journal of Pharmaceutical Analysis, 3 (3), 1-10.

3. ICH Topic Q2 (R1) Validation of analytical procedures: text and methodology.

4. Liliya, L. Dmutro, K., \& Stanislav, S. (2016). Development of methods for identification of calcium channel blockers in medicines. International Journal of Research Ayurveda Pharmaceutical, 7 (2), 88-91.
5. Logoyda L. Development and validation of new methods of analysis for the determination of different natural and synthetic original active pharmaceutical ingredients in medicines / L. Logoyda // Duphat. - 2015. - P. 48.

6. Logoyda L. Validation of chromatographic methods of analysis for the determination of active pharmaceutical ingredients in different medicines / L. Logoyda // Pharma School association for pharmaceutical development and scientific research. Egypt. - 2016. - P. 34.

5. Logoyda, L. (2015). Development and validation of new methods of analysis for the determination of different natural and synthetic original active pharmaceutical ingredients in medicines. Duphat, 48.

6. Logoyda, L. Validation of chromatographic methods of analysis for the determination of active pharmaceutical ingredients in different medicines. Pharma. School Association for Pharmaceutical Development and Scientific Research, 34. 


\section{РОЗРОБКА МЕТОДИКИ ВИЗНАЧЕННЯ ЕНАЛАПРИЛУ В ЛІКАРСЬКИХ ЗАСОБАХ}

\section{Резюме}

Вступ. Тонкошарова хроматографрія - че метод аналізу сумішей шляхом розділення сполук у суміші. Ії можна використовувати для визначення кількості компонентів у суміші, ідентифрікації речовин та встановлення їх чистоти.

Мета дослідження - розробити метод тонкошарової хроматографії для ідентифрікації еналаприлу малеату в лікарських засобах.

Методи дослідження. Метод аналізу еналаприлу малеату описано в Державній Фармакопеї України 2.2, але мета нашого дослідження полягала у розробці швидших, простіших, вибірковіших, точніших, надійніших, менш дорогих методів аналізу еналаприлу малеату та використанні їх для розробки біоаналітичних методів.

Результати й обговорення. Розроблено метод ідентифрікації еналаприлу малеату в лікарських засобах за допомогою тонкошарової хроматографії. Найбільш оптимальний Rf встановлено при використанні рухомої фрази: аміак (25 \%) - пропанол (30:70). Межа виявлення еналаприлу малеату в цій системі становила 0,2 мке. Однак дана мобільна фраза є найбільш вираженою. Було вивчено також деякі характеристики валідації-специфічність та придатність хроматографрічної системи, яка відповідала критеріям прийнятності, встановленим Державною Фармакопеєю України.

Висновок. Було розроблено хроматографрічний метод ідентифрікації еналаприлу малеату в лікарських засобах. Запропонований метод є швидким, економічним та простим.

КЛЮЧОВІ СЛОВА: еналаприл малеат; ідентифікація; тонкошарова хроматографрія; валідація.

\section{РАЗРАБОТКА МЕТОДИКИ ОПРЕДЕЛЕНИЯ ЭНАЛАПРИЛА В ЛЕКАРСТВЕННЫХ СРЕДСТВАХ}

\section{Резюме}

Вступление. Тонкослойная хроматография - это метод анализа смесей путем разделения соединений в смеси. Ее можно использовать для определения количества компонентов в смеси, идентифрикации соединений и установления их чистоты.

Цель исследования - разработать метод тонкослойной хроматографрии для идентифиикации эналаприла малеата в лекарственных средствах.

Методы исследования. Метод анализа эналаприла малеата описан в Государственной Фармакопее Украины 2.2, но чель нашего исследования заключалась в разработке более быстрых, простых, выборочных, точных, надежных, менее дорогостоящих методов анализа эналаприла малеата и использовании их для разработки биоаналитических методов.

Результаты и обсуждение. Разработан метод идентификации эналаприла малеата в лекарственных средствах с помощью тонкослойной хроматографрии. Наиболее оптимальный Rf установлено при использовании подвижной фразы: аммиак (25\%) - пропанол (30:70). Предел обнаружения эналаприла малеата в этой системе составлял 0,2 мке. Тем не менее данная мобильная фраза является наиболее выраженной. Были изучены также некоторые характеристики валидации - специфичность и пригодность хроматографрической системы, которая соответствовала критериям отбора, установленным Государственной Фармакопеей Украины.

Вывод. Был разработан хроматографический метод идентификации эналаприла малеата в лекарственных средствах. Предложенный метод является быстрым, экономичным и простым.

КЛЮЧЕВЫЕ СЛОВА: эналаприл малеат; идентифрикация; тонкослойная хроматография; валидация.

Received 05.07.17

Address for correspondence: L. S. Logoyda, I. Horbachevsky Ternopil State Medical University, Maidan Voli, 1, Ternopil, 46001, Ukraine, e-mail: logojda@tdmu.edu.ua. 